\title{
The influence of conical composite filling on energy absorption during the progressive fracture process
}

\author{
W. Barnat, T. Niezgoda, R. Panowicz \& K. Sybilski \\ Department of Mechanics and Applied Computer Science, \\ Military University of Technology, Poland
}

\begin{abstract}
Energy absorbing composite elements, which can be used for the protection of people, vehicles and structures, have been widely investigated in recent years. Different kinds of materials (metals, composites, foams) and structures have been investigated. Many articles present the glass, carbon and aramid composites investigation results. The sleeve and conical structures are described. The impact energy in these elements is absorbed during the progressive fracture process. Glass composites are very popular due to their low cost.

This paper deals with numerical and experimental research on the possibilities of energy absorption by a conical element made from a glass composite in comparison with a conical composite element filled with polyurethane foam. One element and a small composite panel are investigated and compared.

Keywords: blast wave, energy absorbing element and panel.
\end{abstract}

\section{Introduction}

The problem of energy dissipation by composite absorbing elements is considered from an aspect of the local stability loss or a progressive destruction $[1,2]$. The work, carried out by the destruction of an energy-absorbing element, causes a significant limitation of shock load effects of the construction, for example an impact of the landing platform or an airship with the ground, or the influence of a pressure wave created by an explosion [3].

The greatest absorption energy in relation to a mass unit is possessed by the elements made of composite [4]. 
The aim of this work is the estimation of the influence of the used filling of composite elements on the absorbed energy by the energy-absorbing element in a form of a sleeve filled with a polyurethane foam. Preliminary, quasistatic examinations were carried out on the INSTRON machine, and then they were verified in testing ground conditions.

Cylinder composite elements are characterized by the higher swelling strength initiating destruction processes than the elements with a different geometry (e.g. scones) [5]. In case of these elements, a destruction initiator should be used to protect against catastrophic element destruction. The element destruction in this mode shows that the absorbed energy is considerably smaller than in the case of a progressive destruction.

\section{Description of examined objects}

In this work selected results from numerical-experimental research of following energy-absorbing objects were presented: a composite sleeve, a composite sleeve filled with a polyurethane foam, the system of three sleeves with a destruction initiator, the system of three filled sleeves with a destruction initiator. Additionally, in the work experimental results of loading an energy-absorbing panel, made out of sleeves, with a pressure wave originating from an explosion of an equivalent of $4 \mathrm{~kg}$ of TNT are presented.

In quasi static research the INSTRON testing machine was used. Examined elements were squeezed kinematically with a speed of $0.01 \mathrm{~m} / \mathrm{s}$. During the examination the displacement and the destructive force were recorded.

In the calculations the method of finite elements, implemented in MSC Dytran program, was used. The destruction process was described with the Hashin model.

Composite sleeves (fig. $1 \mathrm{a}$, d) with an internal diameter of $40 \mathrm{~mm}$, height 50 $\mathrm{mm}$ and thickness of walls equal to $3 \mathrm{~mm}$ were made from a glass mat with following properties: $\mathrm{E}_{11}=18.5 \mathrm{GPa}, \mathrm{v}_{12}=0.158, \mathrm{G}_{12}=3.48 \mathrm{GPa}$, and next part of them (fig. $1 b, c)$ were filled with an air-foam - foamed polyvinyl chloride PCHW-1. The foam was characterized by following material properties: $\rho=115$ $\mathrm{kg} / \mathrm{m}^{3}, \mathrm{E}_{\mathrm{r}}=92.4 \mathrm{MPa}, \mathrm{E}_{\mathrm{c}}=80.6 \mathrm{MPa}, \mathrm{R}_{\mathrm{m}}=1.82 \mathrm{MPa}, \mathrm{R}_{\mathrm{c}}=0.911 \mathrm{MPa}$, $v=0.26$.

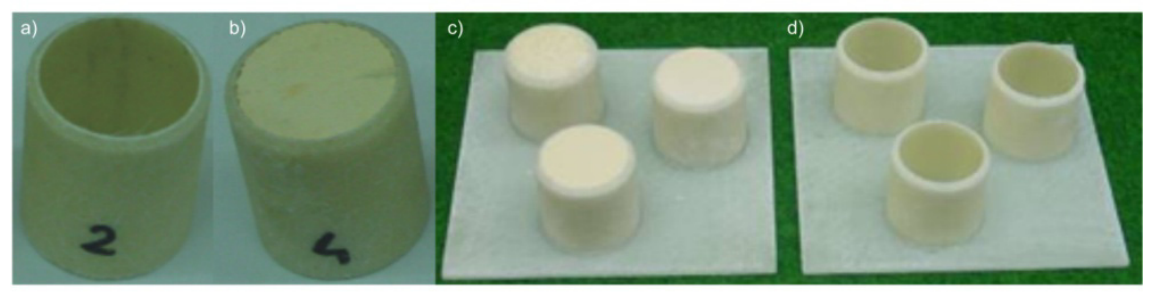

Figure 1: Composite sleeves investigated experimentally.

Their behaviour was described by the generalized Hooke's law [6], that can be used for the description of composite material properties. Physical (of the 
material's model) and geometrical nonlinearities (great displacements and deformations) were taken into account. Calculations were made in the Dytran program containing an implementation of finite elements method.

The numerical model loading (figs. 2 and 3) was put into practice similarly as in carried out experiments by a kinematical input function. Analysed models were loaded by a stiff plate, described by a material of MATRIG type. The superficial contact type was used. It was defined between the bottom plate, energy-absorbing elements, and the striking plate.

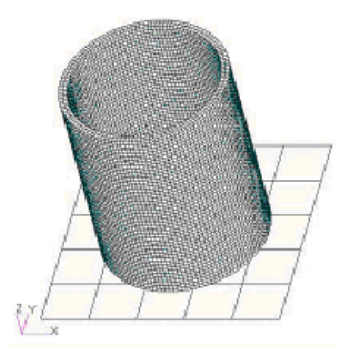

Figure 2: Numerical model of the sleeve.

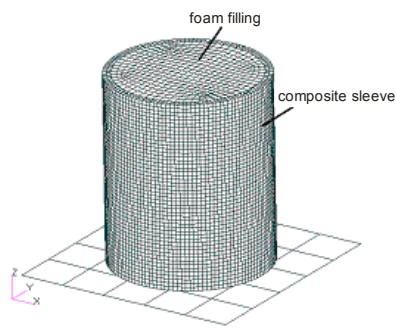

Figure 3: Numerical model of the sleeve with a polymer filler.

\section{Research results for the composite sleeve}

In figure 4, photos from experimental examinations undertaken are presented, and in figure 5 the change of destructive force value from the upper plate displacement in the contact zone is depicted. Analyzing this graph a really great stiffness of the examined object in the initial, linear-elastic zone can be noticed. Then the destruction of examined object was performed under a loading with upsetting force of the order of $23 \mathrm{kN}$.
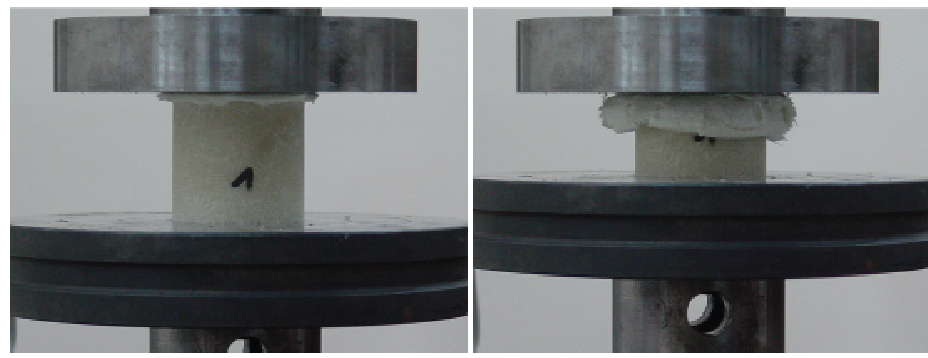

Figure 4: $\quad$ Failure mode of the composite sleeve.

For the same arrangement numerical simulations were made. Deformations of the composite sleeve numerical model are shown in fig. 6. The relative absorption energy was estimated to be about $42 \mathrm{~kJ} / \mathrm{kg}$. 
A sleeve, subjected to the experimental examinations, behaved similarly as the numerical model. The way of the composite sleeve destruction was shown in fig. 6 and in fig. 7 the change of a value of a destructive force in dependence on the upper plate displacement.

Upsetting force graphs, acquired numerically and from experiments, have the same nature, which testifies the correctness of the model's assumptions and the model's material selection.

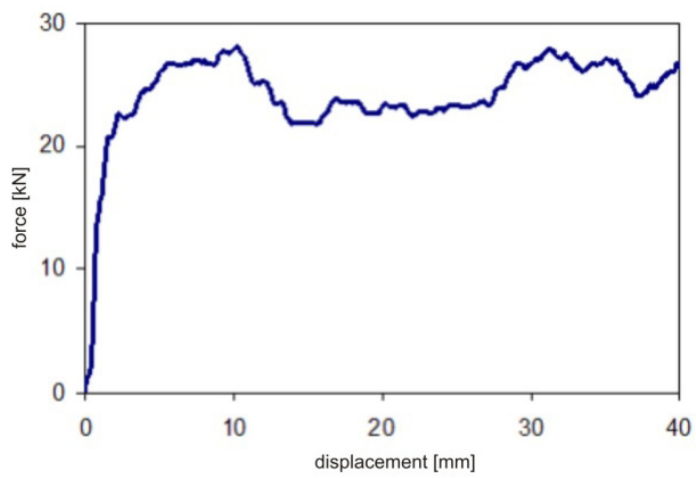

Figure 5: Experimentally obtained compressive force diagram for the composite sleeve.

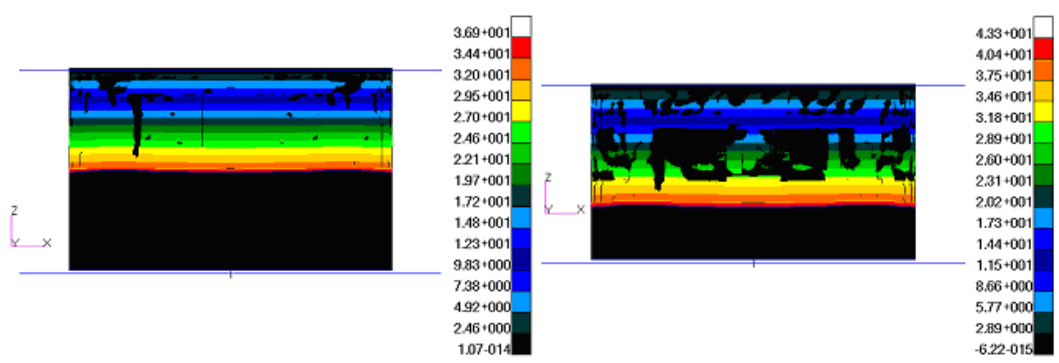

Figure 6: Deformation mode of the composite sleeve numerical model.

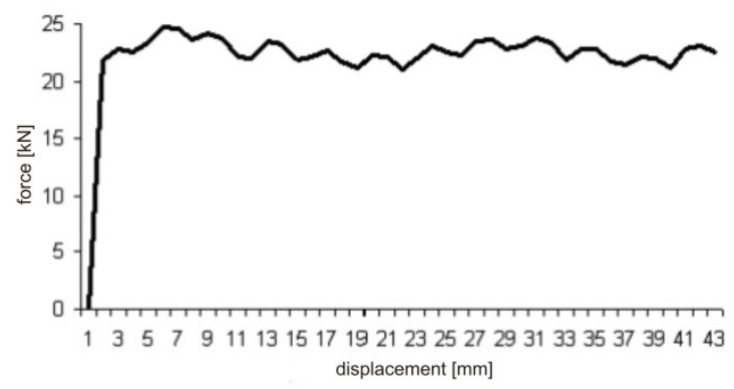

Figure 7: Numerically obtained compressive force diagram for the composite sleeve. 


\section{Research results for the composite sleeve with filling}

As a result of the carried out numerical experiment, a graph of upsetting forces in relation to the displacement was acquired (fig. 8). The use of a filler caused the composite sleeve to be destroyed in a different way than in the former case. The filler precludes the sleeve's burring inside of the model. Upsetting force graph has got a complex character. On the initial part of the graph a clear leap of the upsetting force value up to circa $37 \mathrm{kN}$ is seen. Next its value (thanks to the catastrophic sleeve destruction) falls down and attains the value of $7.5 \mathrm{kN}$. In the next stage of the load the upsetting force value increases. The numerical model of the composite sleeve is being destroyed in a similar was as the real object. The deformation manner of the composite sleeve is presented in fig. 9 .

Based on the numerical calculations it was found that the average upsetting force amounts to $20 \mathrm{kN}$. After taking into account the route that is passed by stiff plates, the upsetting force work was equal to $800 \mathrm{~J}$. After taking into account the examined element's mass it was found that the relative absorption energy for the composite sleeve with a filling amounts to $24.4 \mathrm{~kJ} / \mathrm{kg}$.

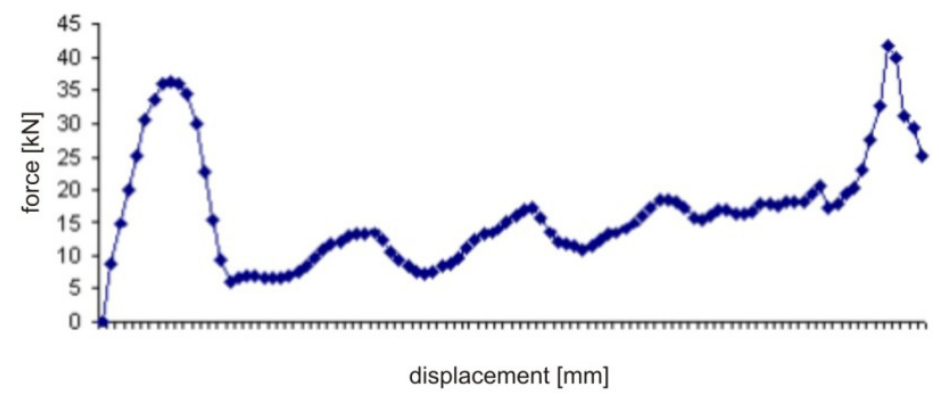

Figure 8: Numerically obtained compressive force diagram for the composite sleeve with a polymer filler.
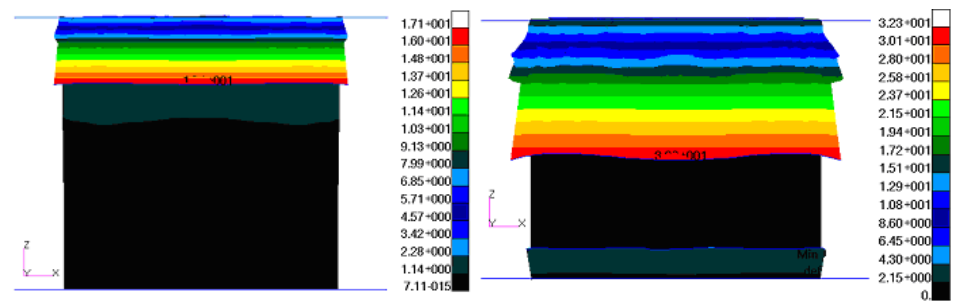

Figure 9: Deformation mode of the numerical model of the composite sleeve with a polymer filler.

The real object behaves similarly as the numerical models. The destruction force graph is presented in fig. 10. In the first stage, the progressive destruction 
of few upper layers took place. Next catastrophic destruction of the sample's part was recorded, characterized by the fall of the loading force and the appearance of a crack on the sample, outside the contact zone. Then the upsetting force is rising gently.

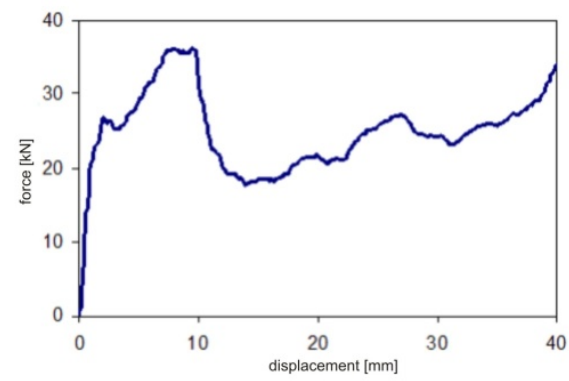

Figure 10: $F(\Delta \mathrm{l})$ graph from the epoxide composite tube reinforced with a glass mat, filled with foam compression.
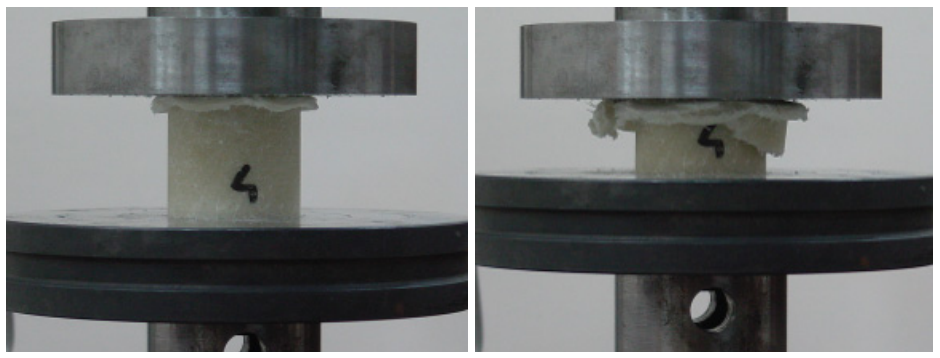

Figure 11: Deformation mode of the numerical model of the composite sleeve with a polymer filler.

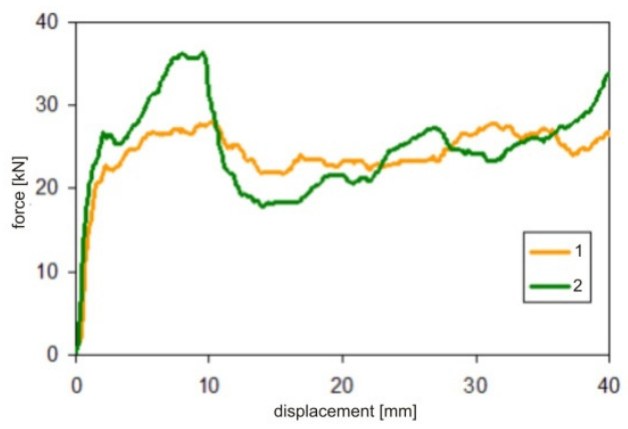

Figure 12: Comparison of vertical reaction value increase graphs obtained experimentally 1 - sleeve 2 - sleeve with filling. 
The matching of the most important data is presented in Table 1.

The use of a filler causes the increase of the absorption energy. The use of a filler also has got its disadvantages. When poorly selected it can cause a deterioration of the element's energy-absorbing properties. In the case of a sleeve with a foam filling a necessity to increase the minimal thickness of walls from circa 2 up to circa $3 \mathrm{~mm}$ exists. Too thin wall doesn't withstand the foam's pressure and yields to catastrophic destruction (the sleeve's crosswise cracking). Whereas a too thick wall can preclude the destruction of the energy-absorbing element, precluding at the same time the stroke's energy absorption.

Table 1: Comparison of obtained results.

\begin{tabular}{|c|c|c|c|c|c|c|c|c|c|}
\hline $\begin{array}{c}\text { Sample } \\
\text { type }\end{array}$ & $\begin{array}{c}\text { Thickness } \\
{[\mathrm{mm}]}\end{array}$ & $\begin{array}{c}\mathrm{D}_{\mathrm{w} 2} \\
{[\mathrm{~mm}]}\end{array}$ & $\begin{array}{c}\mathrm{H} \\
{[\mathrm{mm}]}\end{array}$ & $\begin{array}{c}\mathrm{P}_{\max } \\
{[\mathrm{kN}]}\end{array}$ & $\begin{array}{c}\mathrm{P}_{\text {sr }} \\
{[\mathrm{kN}]}\end{array}$ & $\frac{\mathrm{P}_{\text {sr }}}{\mathrm{P}_{\max }}$ & $\begin{array}{c}\text { EA } \\
{[\mathrm{J}]}\end{array}$ & $\begin{array}{c}\text { WEA } \\
{[\mathrm{kJ} / \mathrm{kg}]}\end{array}$ & $\begin{array}{c}\mathrm{M} \\
{[\mathrm{g}]}\end{array}$ \\
\hline Sleeve & 3 & 39.3 & 50 & 28.1 & 23,1 & 0.822 & 1155 & 44.3 & 26.1 \\
\hline $\begin{array}{c}\text { Sleeve with } \\
\text { a filling }\end{array}$ & 3 & 39.3 & 50 & 36.3 & 25 & 0.689 & 1250 & 37.7 & 33.2 \\
\hline
\end{tabular}

\section{Energy-absorbing panels examination - sleeves}

Results obtained from the experimental examinations for hollow sleeves are presented in figs. 13 and 14. The first figure presents the process of an element's destruction, whereas the second depicts the upsetting force graph. The gentle force rising caused by the use of cracking initiators (in a form of phases) for composite tubes is characteristic for the graph. An average upsetting force was $74.3 \mathrm{kN}$, at the mass of a set amounting to $66.1 \mathrm{~g}$.

The sleeves were being destroyed in a progressive way, mainly through the material's delamination.
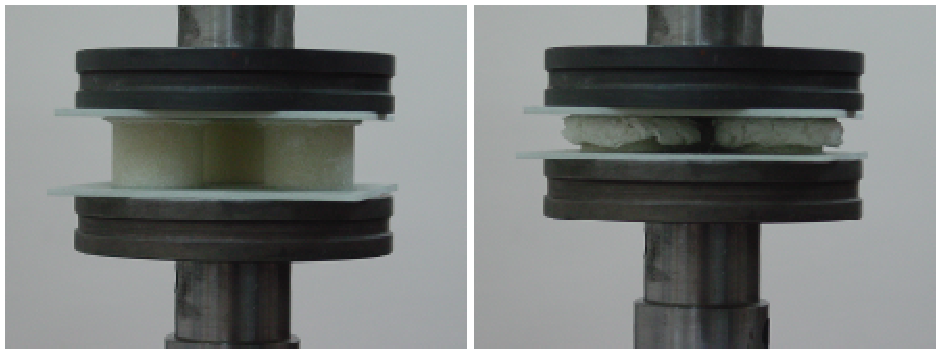

Figure 13: Energy-absorbing panel way of destruction in a form of three composite sleeves.

Absorption energy amounted to $2972 \mathrm{~kJ}$, and the relative absorption energy amounted to $45 \mathrm{~kJ} / \mathrm{kg}$. 


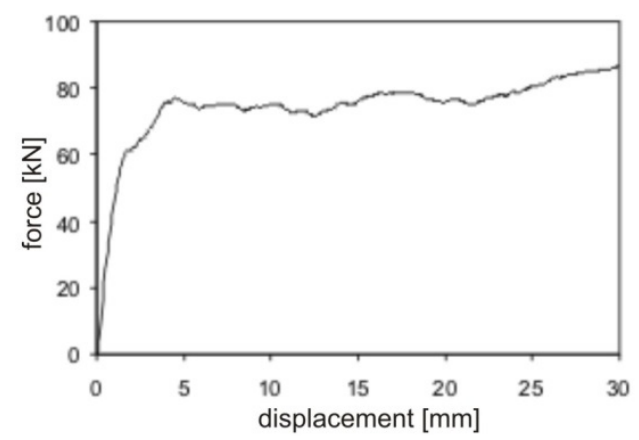

Figure 14: P- $\Delta 1$ dependences for the third energy-absorbing object.

The final character of destruction is presented in fig. 15 .

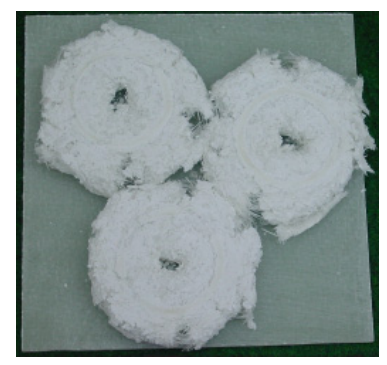

Figure 15: Energy-absorbing panel way of destruction in a form of three composite sleeves.

\section{Energy-absorbing panels examination - sleeves with filling}

Results obtained from the experimental examinations are presented in fig. 16. An air-foam caused a limitation of free delamination of composite elements of energy-absorbing sleeves, which resulted in their catastrophic destruction [7]. With the use of thick-walled elements (wall thickness $3 \mathrm{~mm}$ ) progressive destruction of the element was also acquired but not in all cases. A part of the sleeves with filling examinations ended in the element's catastrophic destruction as presented on the right side of the fig. 16. Most likely it is connected with a great dispersion of mechanical properties of composite elements. To avoid this effect completely, in case of elements filled with foam, the walls thickness should be further increased.

An upsetting force character is presented in fig. 17. Characteristic for the graph is the appearance of the force refraction for the $5 \mathrm{~mm}$ displacement. Such force drop is probably caused by catastrophic destruction of one of the tubes (fig. 18). The mixed destruction process of energy-absorbing elements and the limitation of the possibility of delamination of energy-absorbing elements by the air-foam caused an increase in the upsetting force value. The protective panel 
was destroyed with an average force of the order of $90 \mathrm{kN}$. The maximum force that was measured amounted to, in this case, $105.7 \mathrm{kN}$. In comparison with the former examinations of an object the upsetting force value was 1.13 times greater.
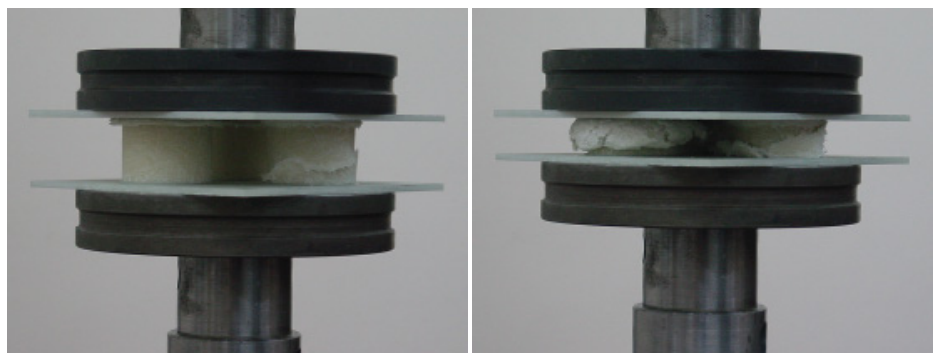

Figure 16: The way of energy-absorbing panel destruction in a form of three composite sleeves filled with air-foam.

The absorption energy, for this case, amounted to $3600 \mathrm{~kJ}$, whereas relative absorption energy - $42,6 \mathrm{~kJ} / \mathrm{kg}$. The statement of the results for panels is presented in Table 2.

Table 2: $\quad$ Comparison of obtained results.

\begin{tabular}{|l|l|l|l|l|l|l|l|l|l|}
\hline Structure & $\begin{array}{l}\text { Thickness } \\
\text { crank }[\mathrm{mm}]\end{array}$ & $\begin{array}{l}\text { Dw2 } \\
{[\mathrm{mm}]}\end{array}$ & $\begin{array}{l}\mathrm{H} \\
{[\mathrm{mm}]}\end{array}$ & $\begin{array}{l}\mathrm{P}_{\max } \\
{[\mathrm{kN}]}\end{array}$ & $\begin{array}{l}\mathrm{P}_{\text {sr }} \\
{[\mathrm{kN}]}\end{array}$ & $\frac{\mathrm{P}_{\mathrm{sr}}}{\mathrm{P}_{\max }}$ & $\begin{array}{l}\text { EA } \\
{[\mathrm{J}]}\end{array}$ & $\begin{array}{l}\text { WEA } \\
{[\mathrm{kJ} / \mathrm{kg}]}\end{array}$ & $\begin{array}{l}\text { M } \\
{[\mathrm{g}]}\end{array}$ \\
\hline 3 Sleeves & 3 & 39.3 & 40 & 86.7 & 74.3 & 0.857 & 2972 & 45.0 & 66.1 \\
\hline $\begin{array}{l}\text { 3 Sleeves } \\
\text { with filling }\end{array}$ & 3 & 39.3 & 40 & 105.7 & 90 & 0.851 & 3600 & 42.6 & 84.5 \\
\hline
\end{tabular}

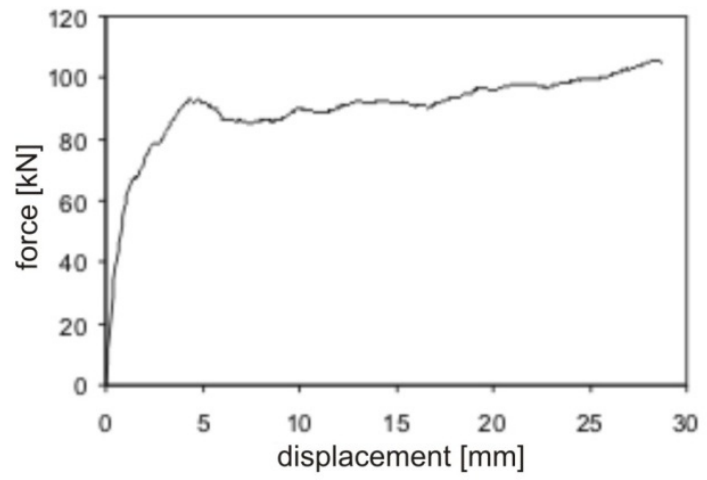

Figure 17: $\mathrm{P}-\Delta \mathrm{l}$ dependence for the second energy-absorbing object. 


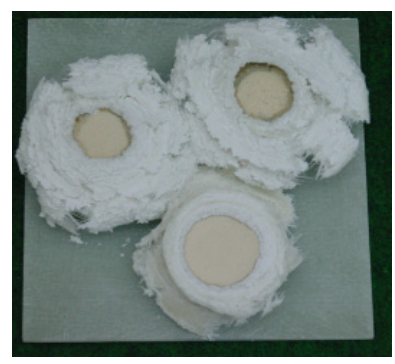

Figure 18: The way of energy-absorbing panel destruction in a form of three composite sleeves with a foam filling.

\section{Testing ground examinations}

Examinations presented above showed the usability of the application of the filling in energy-absorbing elements. That is why testing ground examinations for the panel, presented in fig. 19, with the dimensions $750 \times 750 \mathrm{~mm}$, were made, composed out of 121 composite sleeves. The panel was loaded with a blast wave originating from an explosion of an equivalent of $4 \mathrm{~kg}$ of TNT. The charge was positioned centrally over the panel at the distance of $40 \mathrm{~cm}$ from the panel's top surface.

Comparison examinations were made of a system with a steel plate and the energy-absorbing panel made out of sleeves. After the experiment (fig. 19), in both considered cases, the protected surface and the surface loaded with the pressure wave were scanned. For this task a 3D scanner and software were used. The comparison of deformations is presented in figs. 20 and 21.

The deformation of upper plate, loaded by the blast wave is visible (fig. 20) in the sleeves fastening places and the differences in the final deformation of the considered systems (figs. 20 and 21). In the case of a plate protected for the panel with the sleeves, maximum durable deflection amounts to $15.4 \mathrm{~mm}$, and for the second case $-66.3 \mathrm{~mm}$. This means decreasing of the maximal durable deflection over 4 times in case of an element, where the sleeves were used.

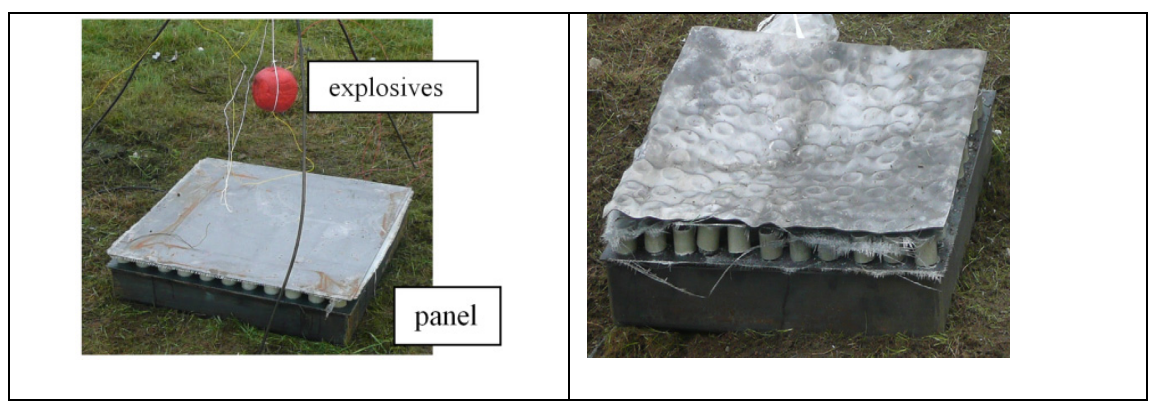

Figure 19: Energy-absorbing panel before and after the experiment. 


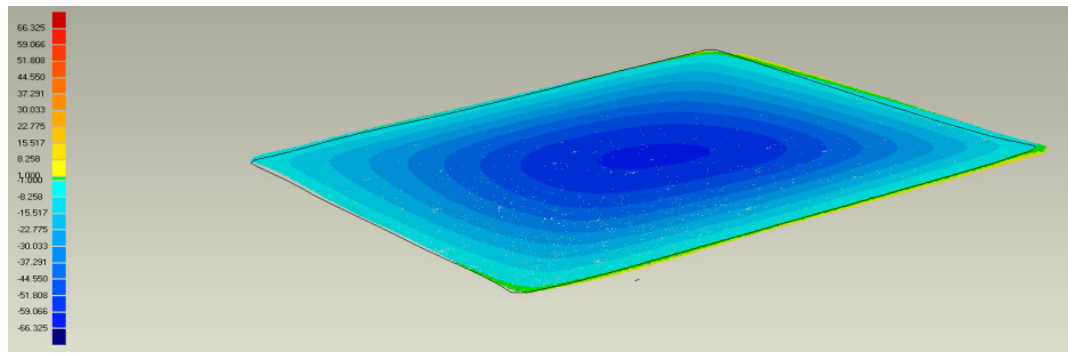

Figure 20: Steel plate deformation burdened with a pressure wave originating from a detonation of an equivalent of $4 \mathrm{~kg}$ of TNT.

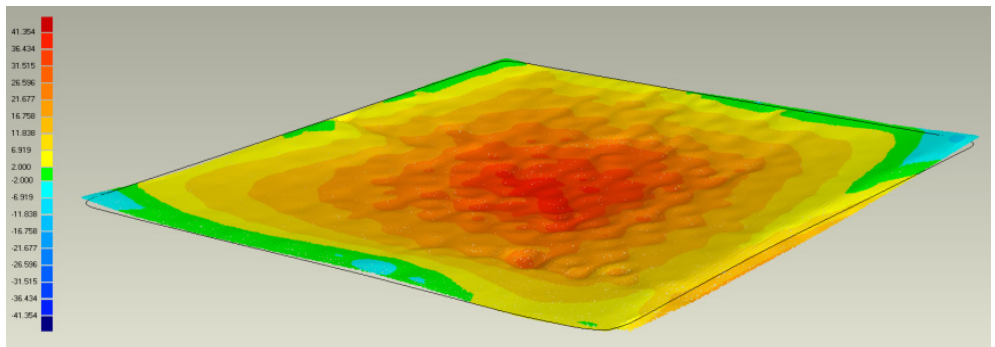

Figure 21: Durable deformation of the plate burdened with a blast wave originating from the detonation.

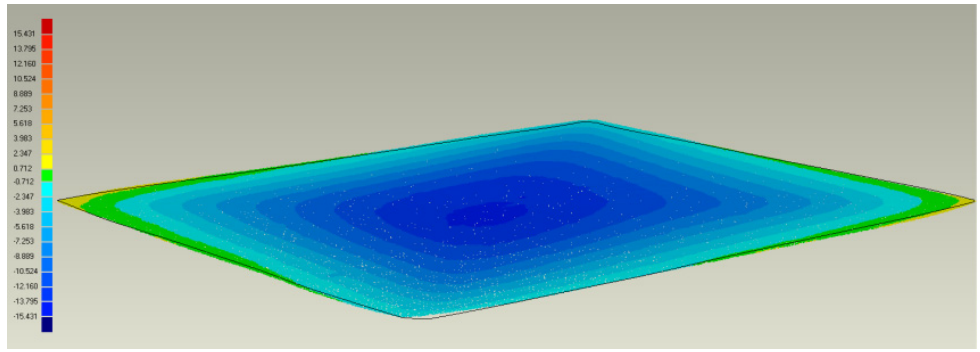

Figure 22: Durable deformation of the protected plate.

\section{Conclusions}

In the work results of numerical examinations with an experimental verification of two energy-absorbing objects are presented. Quasistatic examinations were carried out on the testing machine INSTRON, and dynamical tests on testing ground with the use of explosive materials.

The use of a filling in a form of a foam caused an increase in the absorption energy at the relatively low increase of the protective panel mass. This is quite 
essential in situations, where we have to deal with a limited amount of space, and the energy-absorbing element's mass isn't the main limitation of the designed construction.

Based on the preliminary evaluation of acquired results it was found out that adequate selection of the filler's material should further increase absorbed by the elements energy needed to destroy the examined construction. The authors plan to use for this purpose optimization procedures connected with programs for calculations with finite elements method.

\section{References}

[1] Niezgoda T., Barnat W., Numeryczna Analiza Wptywu Ksztattu Podstawowych Struktur Kompozytowych na Energię Zniszczenia, III Sympozjum Mechaniki Zniszczenia Materiałów i Konstrukcji Augustów, 1 -4 czerwca 2005.

[2] Nagel G., Thambiratnam D. (2003), Use of thin-walled frusta energy absorbers in protection of structures under impact loading. Design and Analysis of Protective Structures against impart/Impulsive/Shock Loads, Queensland.

[3] Niezgoda T., Barnat W.: Analiza pasa bariery drogowej wzmocnionej elementami kompozytowymi w zastosowaniu do poprawy energochłonności elementów infrastruktury Górnictwo Odkrywkowe 5-6/2006.

[4] Barnat W., Niezgoda T.,: Badania energochłonności elementów podatnych $w$ aspekcie zastosowanych materiatów Journal of Kones Powertrain and Transport vol 14 No 1/2007.

[5] Niezgoda T., Barnat W., Numeryczna Analiza Wpływu Ksztattu Podstawowych Struktur Kompozytowych na Energię Zniszczenia, III Sympozjum Mechaniki Zniszczenia Materiałów i Konstrukcji Augustów, 1 -4 czerwca 2005.

[6] MSC Dytran, Example Problem Manual, Version 3.0 MSC 1996.

[7] Niezgoda T., Ochelski S., Barnat W. Doświadczalne badanie wpływu rodzaju wypełnienia podstawowych struktur kompozytowych na energię zniszczenia, Acta mechanica et automatica 1/2007. 